(C) The Author(s), 2021. Published by Cambridge University Press for the Arizona Board of Regents on behalf of the University of Arizona. This is an Open Access article, distributed under the terms of the Creative Commons Attribution-NonCommercial-NoDerivatives licence (https://creativecommons.org/ licenses/by-nc-nd/4.0/), which permits non-commercial re-use, distribution, and reproduction in any medium, provided the original work is unaltered and is properly cited. The written permission of Cambridge University Press must be obtained for commercial re-use or in order to create a derivative work.

\title{
DENDROCHRONOLOGY AND RADIOCARBON DATING
}

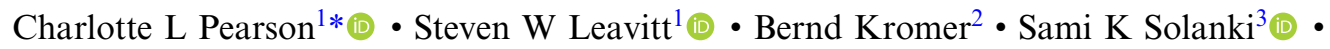 \\ Ilya Usoskin ${ }^{4}$ (i) \\ ${ }^{1}$ Laboratory of Tree-Ring Research, Tucson, AZ, USA \\ ${ }^{2}$ Institute of Environmental Physics, Heidelberg University, Germany \\ ${ }^{3}$ Max-Planck-Institut für Sonnensystemforschung, 37077 Göttingen, Germany \\ ${ }^{4}$ Space Physics and Astronomy Research Unit and Sodankylä Geophysical Observatory, University of Oulu, Finland
}

\begin{abstract}
Both dendrochronology and radiocarbon $\left({ }^{14} \mathrm{C}\right)$ dating have their roots back in the early to mid-1900s. Although they were independently developed, they began to intertwine in the 1950s when the founder of dendrochronology, A. E. Douglass, provided dated wood samples for Willard Libby to test his emerging ${ }^{14} \mathrm{C}$ methods. Since this early connection, absolutely dated tree-rings have been key to calibration of the Holocene portion of the ${ }^{14} \mathrm{C}$ timescale. In turn, ${ }^{14} \mathrm{C}$ dating of non-calendar-dated tree-rings has served to place those samples more precisely in time, advance development of long tree-ring chronologies, and bring higher resolution to earlier portions of the ${ }^{14} \mathrm{C}$ calibration curve. Together these methods continue to shape and improve chronological frameworks across the globe, answering questions in archaeology, history, paleoclimatology, geochronology, and ocean, atmosphere, and solar sciences.
\end{abstract}

KEYWORDS: dendrochronology, radiocarbon history, review.

\section{HISTORICAL DEVELOPMENT OF DENDROCHRONOLOGY}

Growth rings are a prominent internal feature in the stems of woody plants. We may casually notice them in a wide variety of places in our human-built environment such as wooden doors and furniture, or perhaps on an outdoor hike through some natural area where stumps provide a window into the interior of remnant trees. Historical accounts indicate awareness of tree-rings by ancient scholars, such as Theophrastus in $322 \mathrm{BCE}$, who contemplated their annual formation, and Leonardo Da Vinci in the late 1400s CE, who considered weather as influencing their formation (Speer 2010). At least a dozen other scientists in Europe and North America in the 1700s and 1800s made observations or measurements on tree-rings related to climate, weather events, ecology, and human activities (Speer 2010). However, it was not until investigations in the early 1900s by Andrew Ellicott Douglass, considered to be the "founder of modern dendrochronology" (Figure 1A), that a scientific field of study began to emerge.

Douglass was an astronomer, originally based at the Lowell Observatory in Flagstaff, Arizona, near the turn of the 20th century. Among his research interests were the Sun and solar activity manifested in sunspots. Reasoning that solar activity could influence Earth's weather, he investigated tree-rings as indicators of year-to-year climate variability that could then be related to sunspots. During his time in Flagstaff, he noticed the growth rings of ponderosa pine, often on the ends of logs in lumber yards, showing variability in their ring width. He found that inter-annual variability of ring-size contributed to distinctive ring patterns (sequences) that were present in trees over a large region and appeared to be related to year-to-year precipitation variability (Dean 1997). He took a faculty position at the University of Arizona in 1906 to advance his scholarly interests in astronomy while

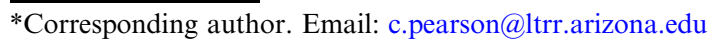



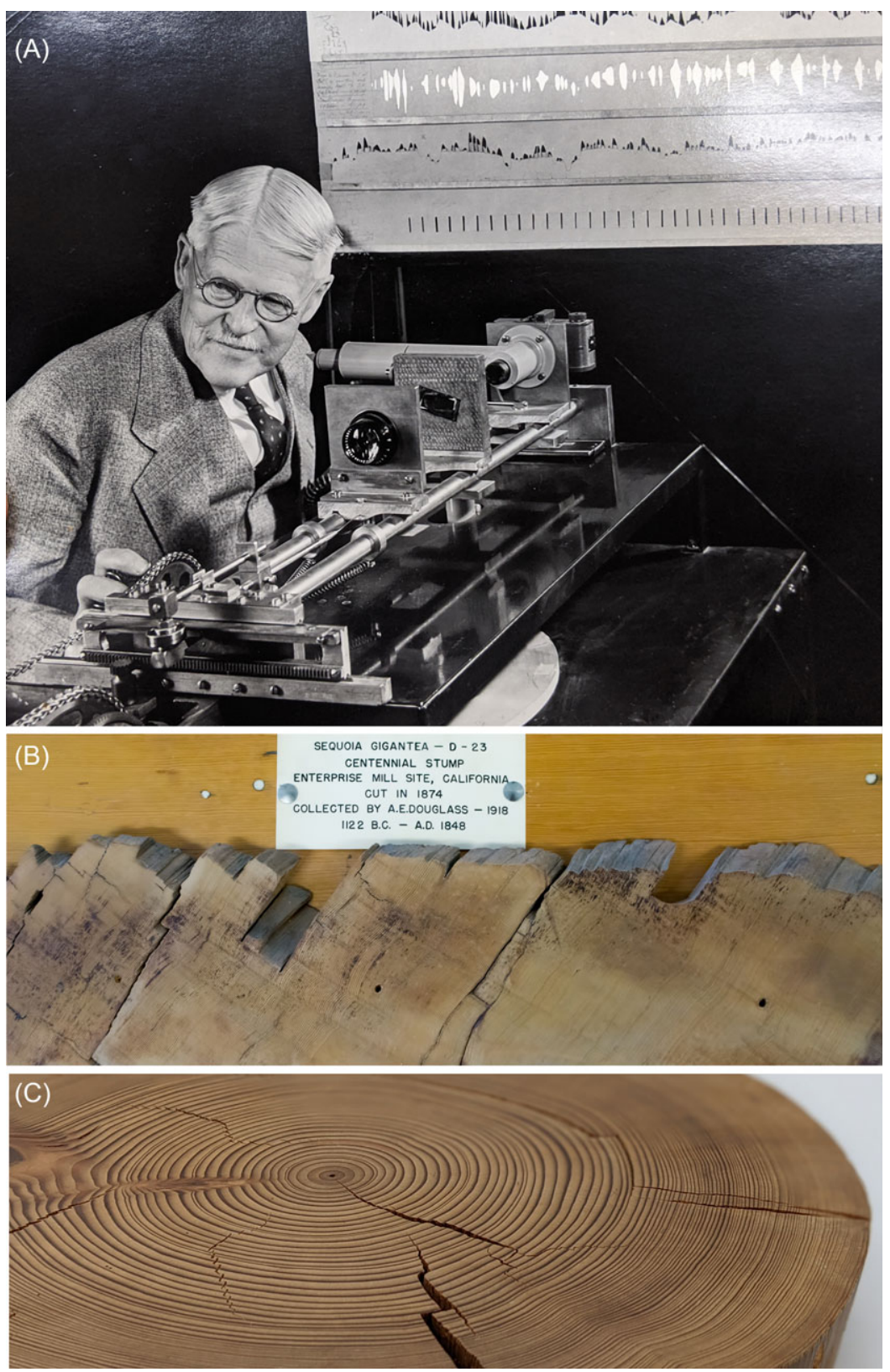

Figure 1 Early tree-ring and radiocarbon interactions: (A) Andrew Ellicott Douglass with his Cycloscope (1935), designed with the over-riding aim of discovering predictable cycles of solar activity in patterns of tree-ring growth, with emphasis on the 11-year solar cycle and its impact on climate (see Webb 1993 for further details). (B) Centennial Stump from California's Sierra Nevada used by Willard Libby in the first radiocarbon calibration, the "Curve of Knowns" featured in his Nobel prize speech in 1960. Note the large notches along the top edge of the sample created by the radiocarbon sampling. (C) Sample from "Broken Flute Cave," an Ancestral Puebloan cliff dwelling in the Prayer Rock district of the Navajo Nation in Arizona, also used in Libby's Curve of Knowns. (All images reproduced with permission from The Laboratory of Tree-Ring Research, University of Arizona.) 
Trees used by people, preserved in historic or archaeological contexts

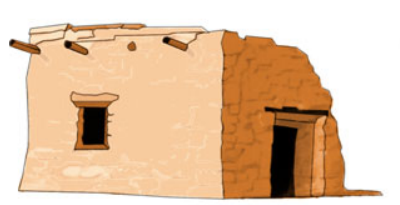

$\downarrow$
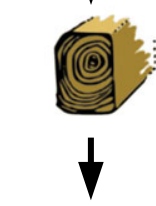

$\downarrow$

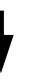

Dead trees preserved in a range of natural environments

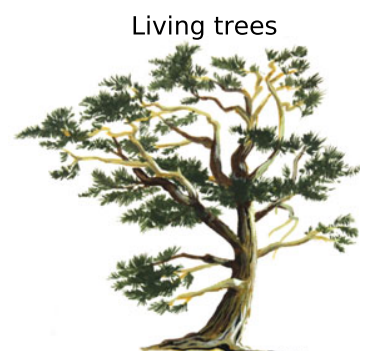

Older samples extend records back in time
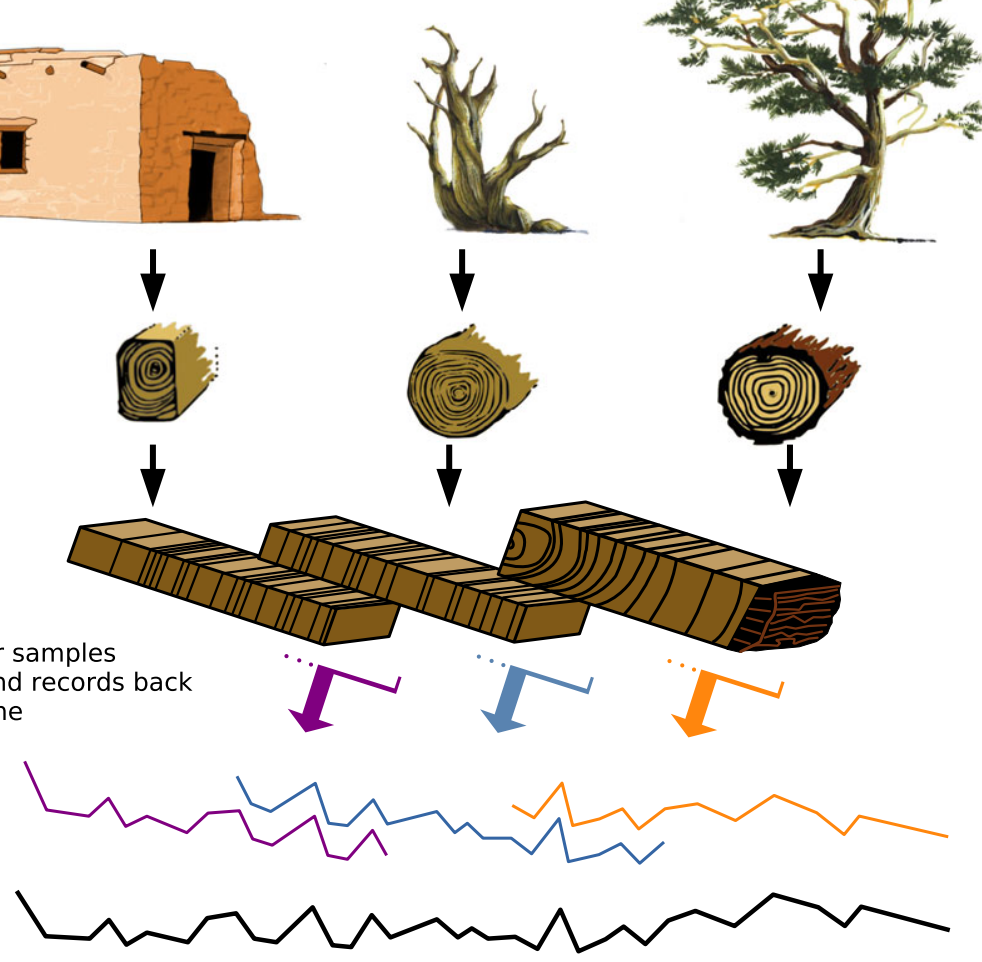

Master chronology

Past

Present

Figure 2 Illustration of the tree-ring crossdating method. Ring-width patterns from areas with common climate forcing show matching patterns of growth, which can be overlapped from successively older samples to develop an extended "master" chronology of ring-width variability. Here the oldest rings in the living tree are shown to match the pattern of growth in the outer rings of a standing dead tree, and in turn the inner rings of the standing dead tree match the outer rings of a beam used in construction of a building. (Image redrawn by $\mathrm{C}$. Pearson based on a composite of images reproduced with permission of LTRR and P. I. Kuniholm, University of Arizona.)

continuing to work with tree-rings, particularly related to archaeological dating in the U.S. Southwest (Douglass 1929). He launched the journal Tree-Ring Bulletin (now Tree-Ring Research) in 1934, and in 1937 he established a new department known as the Laboratory of Tree-Ring Research (LTRR) at the University of Arizona.

Douglass systematically developed field/laboratory methods, principles, and terminology of dendrochronology, which remain in use today. In particular, his principle of "crossdating" (matching of patterns of ring widths among trees to establish absolute dates, see Figure 2) is the linchpin to successful tree-ring studies (Dean 1997; Leavitt et al. 2012). Rather than just "counting rings," crossdating is necessary to identify the temporal correspondence 
between rings with certainty. Furthermore, crossdating identifies "missing rings" and extra rings that are not annual (so-called "false rings"). The method not only applies to matching patterns in contemporaneous living trees, but also to building extended tree-ring-width chronologies. Such long chronologies are produced by matching tree-rings of living trees to patterns in older wood samples from stumps and wood lying on the ground surface, wood in various historic and prehistoric constructions, and logs preserved in waterlogged sediments (see Figure 2). On one hand this crossdating is made possible by the imprint of weather influence on tree growth in a region, and on the other, tree-rings can offer a suitable proxy for climate reconstructions because of this influence. These aspects of dendrochronology are profound and have tremendously and increasingly contributed to historical and archaeological dating, and to a wide variety of investigations involving climate, hydrology, ecology, and geomorphology. Douglass's student and eventual colleague, Edmund Schulman (Figure 3A), was the first to begin developing long tree-ring chronologies from bristlecone pine (Pinus longaeva, Pinus aristata) in California's White Mountains, realizing the great longevity of these trees in that high-elevation mountain environment. Following Schulman's death, C. Wesley (Wes) Ferguson (Figure 3B) was the central bristlecone investigator for almost three decades, arranging expeditions to the White Mountains to extend the chronology. Stimulated by Douglass's successes, Bruno Huber began tree-ring work in Germany in the 1940s, eventually applying the technique to historic and prehistoric buildings (Becker 1992), much as Douglass had successfully done with the archaeological ruins in the American Southwest. Tree-rings have now been studied on all continents (Zhao et al. 2019), even from ancient and petrified wood in Antarctica (e.g., Taylor and Ryberg 2007). Calendar dated ring-width records spanning hundreds and thousands of years have been constructed for multiple regions and the long Northern Hemisphere tree-ring chronologies are paralleled by Southern Hemisphere records.

The longest chronologies for the Northern Hemisphere are from Germany ( $>12,300$ years, oak [Quercus petraea, Quercus robur] and Scots pine [Pinus sylvestris L.]), the European Alps (>9000 years, pine [Pinus cembra], larch [Larix decidua], spruce [Picea abies]), California (>8800 years, bristlecone pine [Pinus longaeva, Pinus aristata]), Finland (>7500 years, Scots pine [Pinus sylvestris L.]), Ireland (>7200 years, oak [Quercus petraea, Quercus robur]), and Siberia (>4000 years, Larch [Larix sibirica]) (see Becker 1992; Kromer 2009; Nicolussi 2009; Eronen 2002; Hantemirov and Shiyatov 2002; Friedrich et al. 2004; Pilcher et al. 1984; Brown and Baillie 2012; Salzer 2019). In the Southern Hemisphere, the longest securely dated sequences are from New Zealand (>4400 years, kauri [Agathis australis]) and Tasmania (>4000 years, Huon pine [Lagarostrobos franklinii C. J. Quinn]) (Boswijk et al. 2006, 2014; Cook et al. 2006). The diverse applications of these multi-functional, calendar-dated tree-ring data continue to enrich the histories of these regions in multiple ways but as remarked by Dean (1997), the primary applications of dendrochronology are for "the dating of past events and the reconstruction of past environmental conditions." Similarly, tree-ring chronologies strike both of these chords with respect to radiocarbon $\left({ }^{14} \mathrm{C}\right)$ applications in that they are used to infer the ${ }^{14} \mathrm{C}$ concentrations in past atmospheres (thereby providing data for carbon cycle investigations and for solar/magnetic reconstruction) and to improve accuracy of dates obtained by radiocarbon methods.

\section{IMPORTANCE OF TREE RINGS TO ${ }^{14} \mathrm{C}$ DATING}

Douglass established the LTRR just a decade or so before Willard Libby at the University of Chicago first developed the radiocarbon dating method and what, in addition to transforming 

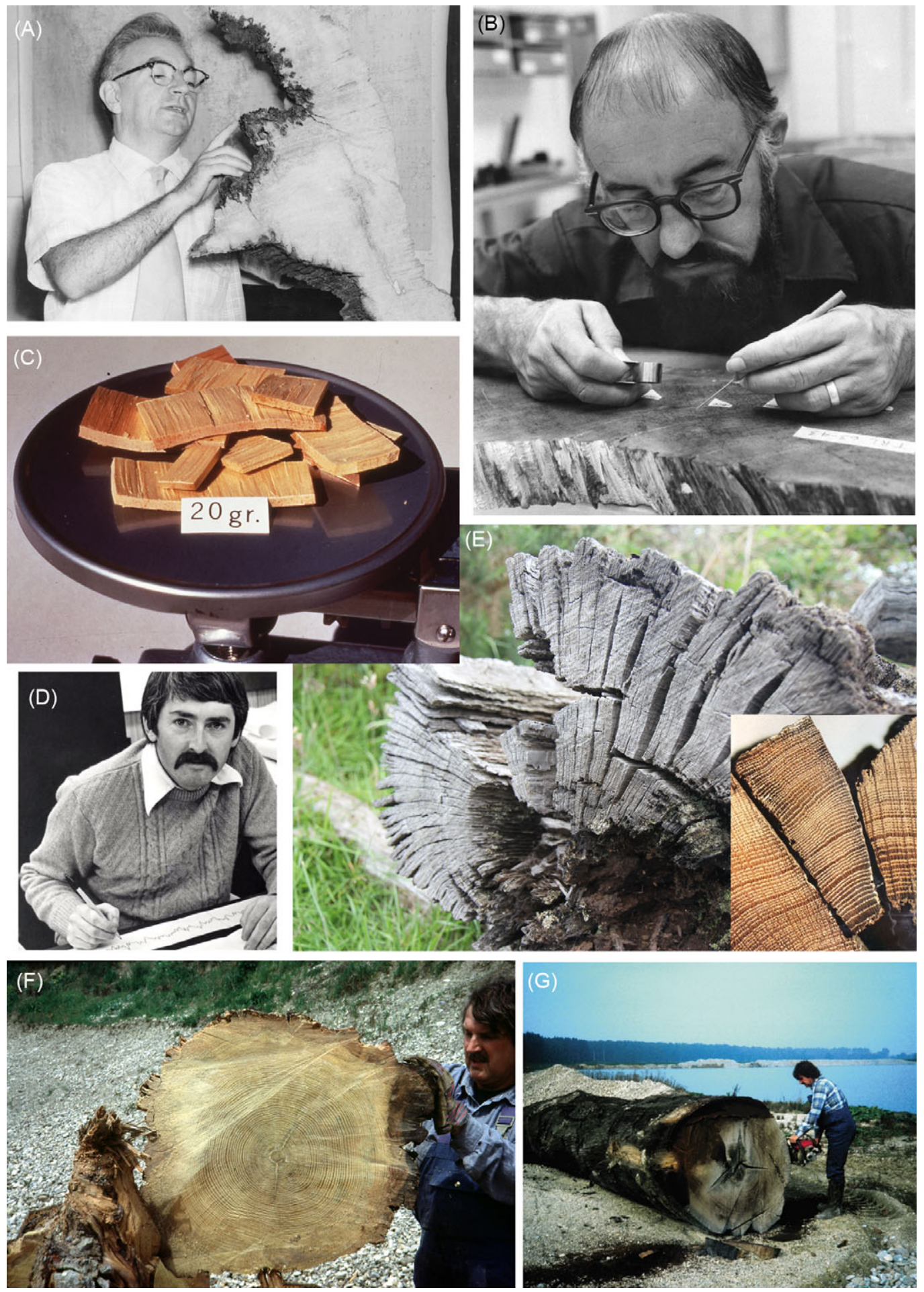

Figure 3 The early long tree-ring chronologies. (A) Edmund Schulman with bristlecone sample \#4779 in 1957; (B) Charles "Wes" Ferguson measuring a bristlecone pine dating 2963 BCE to 278 CE; (C) 20-g sample (10 years) of bristlecone pine prepared at LTRR for requests from radiocarbon dating labs in 1964 and published by Suess (1967); (D) Mike Baillie working on the Irish oak chronology; (E) Irish bog oaks, Garry Bog, (inset) trees from Hillsborough Co. Down, Trinity College Dublin and Coagh Co. Tyrone showing a matching pattern of wide rings, the last being $1580 \mathrm{CE}$; $(\mathrm{F}, \mathrm{G})$ Bernd Becker extracting trees for the European oak and pine chronology. (Images A-C reproduced with permission from The Laboratory of Tree-Ring Research, University of Arizona. D and E provided by M.G.L. Baillie. F \& G provided by B. Kromer.) 
understanding of past timelines, would also become a means to study the solar activity through time, the very motivation for much of Douglass's research. So, since the very inception of these two remarkable disciplines, there has been a kind of symbiosis, with one technique feeding into the other and used in powerful combinations to advance numerous scientific frontiers. This relationship continues to advance and evolve into the present and will no doubt be a focus for future applications.

\section{Calibration and Chronologies}

The critical value of dendrochronology for radiocarbon dating can be distilled as follows: Anywhere around the world, where trees form annual growth rings that can be calendardated using the techniques of dendrochronology, each tree-ring offers a dated sample of atmospheric radiocarbon. Although there are some caveats to this, such as for oak (Quercus sp.), which begins yearly growth using stored carbon from the previous growth season (Pilcher 1995), this basic premise underpins the primary value of dated tree-rings for radiocarbon calibration: Tree-rings offer an independently dated, exact measure of changing radiocarbon levels through time. The first clear demonstrated use of this came in the early development of the radiocarbon dating method (Arnold and Libby 1949) and Libby's "Curve of Knowns" (Libby 1961), featured in his Nobel Prize lecture in 1960, which included measurements of dendrochronologically dated tree-rings from Centennial stump and Broken Flute cave (Figure 1B,C) beginning the long history of LTRR providing tree-ring samples to internal and external ${ }^{14} \mathrm{C}$ researchers (Leavitt and Bannister 2009). Work to test and refine the radiocarbon dating method continued in diverse ways using tree-rings from many growth locations between 1950 and 1970. Spruce (Picea sp.) from Alaska, white pine (Pinus strobus) and incense cedar (Calocedrus decurrens) from North America and Cedrela sp. from the Peruvian Amazon were used by Suess (1955) to compare radiocarbon concentrations in modern wood. Then de Vries $(1958,1959)$ using North American Douglas-fir (Pseudotsuga menziesii) and German oak, detected 1-2\% fluctuations in ${ }^{14} \mathrm{C}$ activity along with the decline in ${ }^{14} \mathrm{C}$ activity over the most recent 100 years related to ${ }^{14} \mathrm{C}$ dilution by carbon dioxide from combustion of ${ }^{14} \mathrm{C}$-free fossil fuels, which Suess (1955) had previously identified (known as the "Suess effect"). Suess (1965) then went on to verify de Vries' original observations of ${ }^{14} \mathrm{C}$ wiggles (the "de Vries effect") using dendrochronologically dated North American sequoia (Sequoiadendron giganteum), Douglas-fir and ponderosa pine (Pinus ponderosa). Stuiver (1965) also independently verified the de Vries wiggles at high-resolution using North American Douglas-fir, thus tree-rings were central to establishing the first links between these features and solar activity that modulates ${ }^{14} \mathrm{C}$ production (Stuiver 1961; Damon and Peristykh 2000). This work also underpins the premise for radiocarbon wigglematch dating, where several radiocarbon dates sampled from a non-calendar dated (or floating) tree-ring sequence, spaced by exact ring counts, can be used to find a more precise fit of the wiggles (slopes and plateaus) against the radiocarbon calibration curve, so narrowing the possible date range for end point (outermost ring) of that sequence. Wiggles in the calibration data-sets also limit the dating precision and accuracy achievable for particular time periods.

Meanwhile dendrochronological work on North American bristlecone pine (Schulman 1954; Pritchett 2021) had led to these remarkable long-lived trees becoming the basis for the world's first multi-millennial tree-ring time-series (Ferguson 1969). The value of this material for radiocarbon calibration and testing the method was also realized by Suess (1967), who demonstrated that for the period between $4100 \mathrm{BCE}$ and $1500 \mathrm{BCE}$ (extended back to 
5200 BCE, Suess 1970), the radiocarbon content of 80 multi-year blocks of calendar-dated bristlecone pine tree-rings (see Figure 3C for a typical sample) was between 6 and 9\% higher than what had been calculated for the same time period using the radiocarbon halflife. This correction and time-series was used in some of the first attempts to synchronize archaeological sequences that were critical to old world chronology (Clark 1978) and to secure one of the first-ever radiocarbon wiggle-matches (Ferguson et al. 1966) of noncalendar secured tree-ring sequences from the archaeological pile-dwelling site of Burgäschisee in Switzerland. In this study, ${ }^{14} \mathrm{C}$ in the calendar-dated bristlecone pine sequence was used to secure ${ }^{14} \mathrm{C}$ measurements from the undated Swiss samples, assigning them to the 38 th century BCE with an error less than 40 years.

As dendrochronology became a globally utilized science, multiple tree-ring sequences were developed in different regions, opening up more and more opportunities for crosspollination of radiocarbon and tree-ring research. At Queen's University Belfast in Northern Ireland, the idea to produce a ${ }^{14} \mathrm{C}$ timescale for Holocene peat and lake deposits in Northern Ireland and to answer questions raised by the bristlecone pine-based calibration curve (Suess 1970) was in fact a driving force behind the development of the long Irish tree-ring chronology that utilized oak trees preserved in Irish bog and terrestrial environments (Baillie 2009; Figure 3D,E). As work progressed on the construction of the Irish tree-ring chronology, in Germany, Burghart Schmidt and Bernd Becker, and separately Hubert Leuschner and Axel Delorme, were working on parallel chronologies, published back to 2000 BCE in 1982 (Becker and Schmidt 1982) and back to 4004 BCE (Leuschner and Delorme 1984) using oaks and pines retrieved from riverine flood deposits (Figure 3F,G). At the time of Becker and Schmidt's (1982) publication, the Irish chronology was back to 5289 BCE (Baillie 2009) and an initial comparison of these two records across a 1000-year test period raised an issue. The two groups of tree-ring patterns matched with certainty, but the dates applied to each chronology did not synchronize, revealing a 71-year discrepancy in the dating applied to the two records. Which was correct? Here, radiocarbon "wiggle-matching" of sections of the German chronology to the bristlecone pine calibration curve, played a part in resolving the discrepancy, by revealing that the German record was off-set by ca. 70 years relative to the bristlecone pine, almost the exact discrepancy revealed by the dendrochronological comparison with the Irish oak record. As a result the dendrochronological issue (which it turned out was because dating for the pre-550 BCE portion of Becker and Schmidt's chronology was based on a single site chronology produced and misdated by Ernst Hollstein [1980]) was swiftly identified and resolved (Pilcher et al. 1984; Baillie and Pilcher 1987), resulting in the joint publication of an agreed European oak chronology back to 5289 BCE (Pilcher et al. 1984). This happened to coincide exactly with the publication of the alternate German oak record, developed by Leuschner and Delorme (1984), which did not contain the 71-year error included in Becker and Schmidt's record, and so provided a fully independent dendrochronological confirmation of the Pilcher et al. (1984) chronology. Following this, the German chronology was expanded back to 9420 BCE (see table 4.1 in Becker 1993; Becker and Schmidt 1990). Meanwhile, combined dendrochronological and radiocarbon effort continued towards the creation of a series of high-precision radiocarbon calibration curves for terrestrial Northern Hemisphere samples using ${ }^{14} \mathrm{C}$ measurements from Irish and German oak, German pine and North American conifers including bristlecone pine. These were measured primarily at the Seattle, Belfast, Heidelberg, and Arizona radiocarbon laboratories and extended back to 13,300 cal BP by 1986 (Stuiver et al. 1986; Pearson et al. 1986). The Hohenheim oak and pine chronology, currently the world's 
longest calendar-dated tree-ring sequence at 12,460 years (Friedrich et al. 2004), facilitated the further extension of this calendar-dated ${ }^{14} \mathrm{C}$ record for calibration in more recent years (Stuiver et al. 1998; Reimer et al. 2009, 2013), in combination with the European Preboreal Pine and Swiss chronologies. This is now reinforced by the inclusion of single-year subfossil pine data from the French Alps (Reinig et al. 2020) to extend the latest iteration back to $14,226 \pm 4$ cal BP (Reimer et al. 2020).

Out of these previously described early cross-pollination events between dendrochronology and radiocarbon dating also came some of the first research into interhemispheric calibration (McCormac et al. 1998, 2002; Hogg et al. 2002), the study of regional ${ }^{14} \mathrm{C}$ offsets (McCormac et al. 1995-see Reimer et al. 2020 for a detailed discussion of these) and explorations of the complexities of ${ }^{14} \mathrm{C}$ mixing in the intertropical convergence zone (McCormac et al. 2004).

The Southern Hemisphere has a larger ocean surface area than the Northern Hemisphere (ca. $60 \%$ compared to ca. $40 \%$, respectively) and greater wind velocities. The effects of this on ocean/atmosphere transfer mean that natural levels of ${ }^{14} \mathrm{C}$ in the southern troposphere are usually lower than in the northern troposphere. This means that radiocarbon ages for terrestrial samples from the Southern Hemisphere can be expected to measure older than contemporary terrestrial samples in the Northern Hemisphere by ca. 40 years. Radiocarbon measurements on contemporary pairs of tree-ring samples from Northern Hemisphere (Quercus petraea) and Southern Hemisphere (Libocedrus bidwilliilManoao colensoi) trees at the Belfast and Waikato radiocarbon laboratories (McCormac et al. 1998, 2002; Hogg et al. 2002) for the period AD 1850-950 however showed that a fixed "offset" should not be applied to Northern Hemisphere radiocarbon calibration data in order to use it to calibrate Southern Hemisphere radiocarbon measurements. Instead, the Southern Hemisphere required its own separate calibration curve. Tree-ring measurements from New Zealand, Chile and South Africa combined to form the basis of the first (and subsequent) curve iterations (SHCal02-McCormac et al. (2002); SHCal04-McCormac et al. (2004); SHCal13-Hogg et al. (2013)). In the most recent iteration, SHCal20 (Hogg et al. 2020) 14 new tree-ring data sets are added in the 2140-0, 3520-3453, 3608-3590, and 13,140-11,375 cal BP time ranges. The first three of these periods provide calendar-dated calibration reference material, and the latter brings annual resolution data via a floating tree-ring sequence. In between these periods, the current SH curve still lacks direct SH observations and relies on the corresponding sections of the Northern Hemisphere curve as a modeling basis. Fortunately, dendrochronology of New Zealand kauri in particular offers many future possibilities to fill in some of these gaps and extend measurements further back in time (Boswijk et al. 2014; Lorrey et al. 2018).

\section{Other Synergies and Applications}

The transition between the Northern and Southern Hemispheric atmospheres lies along the Intertropical Convergence Zone (ITCZ). Seasonal shifts in the ITCZ may entrain atmospheric $\mathrm{CO}_{2}$ from the Northern and Southern Hemisphere to sites in this region within a given year and be impacted by a number of climatic forcings. Evidence for the migration of the ITCZ on multi-decadal to millennial time scales has been seen in a wide range of proxy records (e.g., Jacobel 2017), but tree-ring ${ }^{14} \mathrm{C}$ records offer excellent potential for fine-scale geographic coverage and high-resolution reconstructions. Studies utilizing ${ }^{14} \mathrm{C}$ distribution in Mexican tree-rings have shown the influence of the North American 
Monsoon on the position of the ITCZ (Beramendi-Orosco et al. 2018), and these data also offer much potential for correcting archaeological chronologies within this region where calibration uncertainties are high due to the atmospheric mixing of ${ }^{14} \mathrm{C}$ (see Marsh et al. 2018). Another beneficial feedback between disciplines here is that typically the tropics have a scarcity of trees suitable for traditional dendrochronological methods, so a combination of radiocarbon and dendrochronology can be used to first confirm the presence of annual increments in trees (Santos et al. 2020) and then to go on to explore how these increments might be used in tracing the ITCZ and the forces governing its movement. In particular, use of the ${ }^{14} \mathrm{C}$ bomb spike, caused by nuclear bomb testing in the 1960s CE, which almost doubled atmospheric ${ }^{14} \mathrm{C}$ levels at this time before a steady decline due to ocean surface transfer processes and carbon cycling, produced an artificial tracer with which to date more recent organic material. Vieira et al. (2005), used the bomb spike to determine ages of tropical trees from the Brazilian Amazon without clear tree-ring structures, inferring tree growth rates and their consequences to carbon cycle modeling of forest biomass turnover. Radiocarbon dating and dendrochronology techniques have also been applied to see if African baobab trees, which have hollow inner cavities, could be dated using size-age relationships (Patrut et al. 2011) and if monumental olive trees in Spain (Camarero et al. 2021) and Israel (Bernabei 2015) were as old as purported by local populations. Olive trees are frequently encountered in key contexts in the ancient Mediterranean and Near East and have been the focus of much recent study (Ehrlich et al. 2018, 2021) to aid with use in the dating of archaeological contexts (e.g., Friedrich et al. 2006, 2014; Cherubini et al. 2013).

\section{THE SOLAR AND GEOMAGNETIC CONNECTION}

\section{Past Solar Activity}

The solar activity that so fascinated Douglass can now be explored directly through radiocarbon measurements from tree-rings and compared with documented visual observations of sunspots over the past four centuries, and instrumental data from recent decades (Solanki et al. 2013). The significance of ${ }^{14} \mathrm{C}$ in tree-ring chronologies as a tool to reveal the temporal variability of solar activity over past millennia was realized early in the history of ${ }^{14} \mathrm{C}$ studies and pioneered largely using coarser resolution ${ }^{14} \mathrm{C}$ from multi-year blocks of tree-rings. However, as discussed by Stuiver (1961) and Suess (1965), and summarized by Lingenfelter (1963), the precision and temporal resolution of these ${ }^{14} \mathrm{C}$ data were insufficient to discriminate production and carbon cycle (oceanic) causes of the observed ${ }^{14} \mathrm{C}$ variations.

In the late $1970 \mathrm{~s}$ a precision of 1.5 to $2 \%$ was reached in the ${ }^{14} \mathrm{C}$ laboratory of Seattle, and Stuiver and Quay (1980) published a detailed and statistically convincing comparison of ${ }^{14} \mathrm{C}$ in decadal tree-ring samples, observing sunspot numbers (averaged over 11-year cycles) from 1620 to $1880 \mathrm{CE}$. They also found strong ${ }^{14} \mathrm{C}$ maxima corresponding to three grand solar minima, the Wolf, Spörer, and Maunder, with very low solar activity for several decades, and discussed the heliomagnetic modulation of galactic cosmic rays, leading to production changes of the cosmogenic isotopes ${ }^{14} \mathrm{C},{ }^{10} \mathrm{Be}$, and ${ }^{36} \mathrm{Cl}$. Using IntCa198, Solanki et al. (2004) reconstructed decadal sunspot numbers back to 11,000 years BP and determined the distribution of grand solar maxima and minima. Also based on IntCa198, Usoskin et al. (2007) analyzed the statistics of grand minima and maxima, concluding that the occurrence of these events is characterized by a stochastic/chaotic process, and that they represent special states of the solar dynamo. 


\section{Solar Cycles and ${ }^{14} \mathrm{C}$ Production Spikes}

Initial measurements of ${ }^{14} \mathrm{C}$ in annual rings over intervals of $10-20$ years were limited by the precision of the measurements. After early inconclusive efforts to identify the solar cycle in 20th century tree-rings, Damon et al. (1973) concluded that radiocarbon "measurement errors [did] not allow precise determination of the relatively small amplitude of the atmospheric radiocarbon variation due to the 11-yr solar cycle." Statistically robust observations of the solar 11-year cycle in ${ }^{14} \mathrm{C}$ had to wait until the early 1990 s, when Stuiver and Braziunas (1993) measured annual ${ }^{14} \mathrm{C}$ content in tree-rings for $1510-1954 \mathrm{CE}$. At those times, lowlevel gas counting detectors required $20-30 \mathrm{~g}$ of wood per ring and extended counting times of a week or more per sample. Hence, only a rather limited interval of 1510-1954 CE could be considered; as noted by Minze Stuiver (1993): "the counting time for producing the 440-yr single-year series reported here is identical to that needed for an 8800-yr bidecadal chronology." Stuiver and Braziunas (1993) found a statistically significant correlation between sunspot numbers and annual ${ }^{14} \mathrm{C}$ data during $1715-1948 \mathrm{CE}$.

Fortunately, the AMS technique is ideal for annual ${ }^{14} \mathrm{C}$ measurements on wood samples, even single tree-rings, because it can work with a low sample mass $(<50 \mathrm{mg})$ with counting times per sample of only a few hours, i.e., two orders of magnitude lower compared to radiometric lowlevel counting (LLC). Routine precision of $<2 \%$ in AMS has only become a reality in the past decade (Wacker et al. 2020), leading to several series of centennial-long annual ${ }^{14} \mathrm{C}$ data sets. This work has been further propelled by the discovery of an incredible increase of $\Delta^{14} \mathrm{C}$ of $15 \%$ in single tree-rings covering the years 774 to 775 CE by Miyake et al. (2012). McCormac et al. (2008) had previously noted this increase within a 10-yr resolution time series based on the Irish oaks, reporting a rapid enrichment of ${ }^{14} \mathrm{C}$ between 765 and $775 \mathrm{CE}$, but the discovery that this change was in fact an abrupt event occurring between two single years opened a wide range of new research. Initially, a supernova, gamma-ray burst, or an extreme solar event were discussed as a possible cause for this phenomenon, but later comparison with ${ }^{10} \mathrm{Be}$ (Usoskin et al. 2013) and additionally ${ }^{36} \mathrm{Cl}$ (Mekhaldi et al. 2015) led to an unambiguous identification of an extreme solar proton event (SPE) as the source. The realization that such events can be identified, and their magnitude and re-occurrence tracked via annual ${ }^{14} \mathrm{C}$ has led to a global scale search of annual (and sub-annual) tree-ring ${ }^{14} \mathrm{C}$ for more such events and other solar cycles, solar maxima and minima, not visible in the previous coarser-resolution records (Miyake et al. 2013, 2017; Güttler et al. 2015; Neuhäuser et al. 2015; Sukhodolov et al. 2017; Jull et al. 2018; Uusitalo et al. 2018; Scifo et al. 2019; Friedrich et al. 2019).

So far two more SPEs have been confirmed: 993 CE (Miyake et al. 2013) and 660 BCE (Park et al. 2017; O'Hare et al. 2019; Fahrni et al. 2020), and three more candidates have been tentatively identified. These are at 3372 BCE (Wang et al. 2017; but this was not confirmed by Jull et al. 2021), $1052 \mathrm{CE}$ and $1279 \mathrm{CE}$ (Brehm et al. 2021) but they need further confirmation with independent tree-ring chronologies. The global nature of the 775 and 993 $\mathrm{CE}$ events has meanwhile been confirmed in a study involving annual ${ }^{14} \mathrm{C}$ series of 44 treering chronologies of five continents (Büntgen et al. 2018), demonstrating the unique "signature year" character of SPEs to link chronologies worldwide. Replicate annual measurements in the respective century of the 1052 and $1279 \mathrm{CE}$ events were published by Kudsk et al. (2019).

The longest and most precise annual ${ }^{14} \mathrm{C}$ dataset so far has been created by Brehm et al. (2021) using 13 oak timbers from buildings in the UK and Switzerland (full details are given in the 
supplement of Brehm et al. 2021) and covering the period 969-1933 CE. It shows the persistence of the 11-yr Schwabe cycle throughout the last millennium, with a $\Delta{ }^{14} \mathrm{C}$ amplitude of $0.9 \%$ during solar maxima and $0.6 \%$ during minima, and an average length of 10.4 yr. Details of the Wolf, Spörer, and Maunder minima have been studied in annual ${ }^{14} \mathrm{C}$ data by Eastoe et al. (2019), Fogtmann-Schulz et al. (2019, 2020), and Moriya et al. (2019). These same data were used by Land et al. (2020) to connect with the broader scope of dendrochronology by comparing the record of solar forcing with climatic impact on tree-ring growth for the same years. This is an exciting study in that it combines annually resolved paleoclimatic and solar proxies from the same calendar-dated tree-ring sequence and shows a direct influence of the Schwabe cycle on climate. It reaffirms that ${ }^{14} \mathrm{C}$ in treering chronologies can provide information on solar variability on time scales of years to centuries and millennia.

\section{Earth's Magnetic Field}

The Earth's magnetic field protects Earth against the solar wind and helps it shield against cosmic rays that produce radiocarbon in the upper atmosphere, with implications for Earth radio communications, satellite networks and life on Earth (Channell and Vigliotti 2019). The magnetic field strength, position, and polarity have long been known to vary over millions of years based on measurement of remanent magnetism in rocks (Kono 2007, remanent magnetism is the permanent magnetism in rocks, resulting from the orientation of the Earth's magnetic field at the time of rock formation in a past geological age) but multi-millennial-scale production changes of cosmogenic isotope abundance are also considered to be caused mainly by these geomagnetic variations (Beer et al. 2012). Highresolution production records showing the "secular trend" of modulation by the Earth's magnetic field were originally derived from radiocarbon measurements on long tree-ring sequences as part of the early calibration-curve development efforts, which revealed longterm quasi-sinusoidal variation in radiocarbon production (Sonett and Finney 1990). Between 1970 and 1990 atmospheric ${ }^{14} \mathrm{C}$ reconstructions from tree-rings were used to infer changes of the global magnetic dipole moment, assuming a constant carbon cycle (Damon and Linick (1986); Stuiver et al. (1991) and references therein). Geomagnetic measurements on sediments and rocks are now the primary source of information about Earth's magnetic field. Calculating this field requires a record of global dipole moment that is modeled from localized data covering part of the globe, which has only recently converged through three different models (e.g., Nilsson et al. 2014).

\section{Solar Reconstructions and ${ }^{14} \mathrm{C}$ Spike Dating}

The discussion of the full sequence of solar variability, solar-terrestrial interactions and the response of the climate system is outside the scope of this paper (see Haigh (2007) and Gray et al. (2010) for reviews). The first steps involving reconstruction of sunspots and of total solar irradiance (TSI) or solar spectral intensity (SSI) have been gradually developed in response to the progress in determining atmospheric ${ }^{14} \mathrm{C}$ over the Holocene and the availability of ${ }^{10} \mathrm{Be}$ data from polar ice cores. Steinhilber et al. (2012) reconstructed TSI from a combination of 2000-yr high-pass filtered ${ }^{14} \mathrm{C}$ in $\mathrm{IntCa} 09$ and ${ }^{10} \mathrm{Be}$ from seven ice cores in Greenland and Antarctica, and compared TSI to the $\delta^{18} \mathrm{O}$ record of Dongge cave, China, thought to represent a signal of the Asian monsoon, revealing a significant correlation. Wu et al. (2018a, 2018b) presented the latest reconstruction of sunspots and TSI (Figure 4) and SSI back to $6755 \mathrm{BCE}$ from ${ }^{14} \mathrm{C}$ and ${ }^{10} \mathrm{Be}$. The range of the TSI variability on a millennial scale is determined to be ca. $0.11 \%\left(1.5 \mathrm{~W} \mathrm{~m}^{-2}\right)$. 


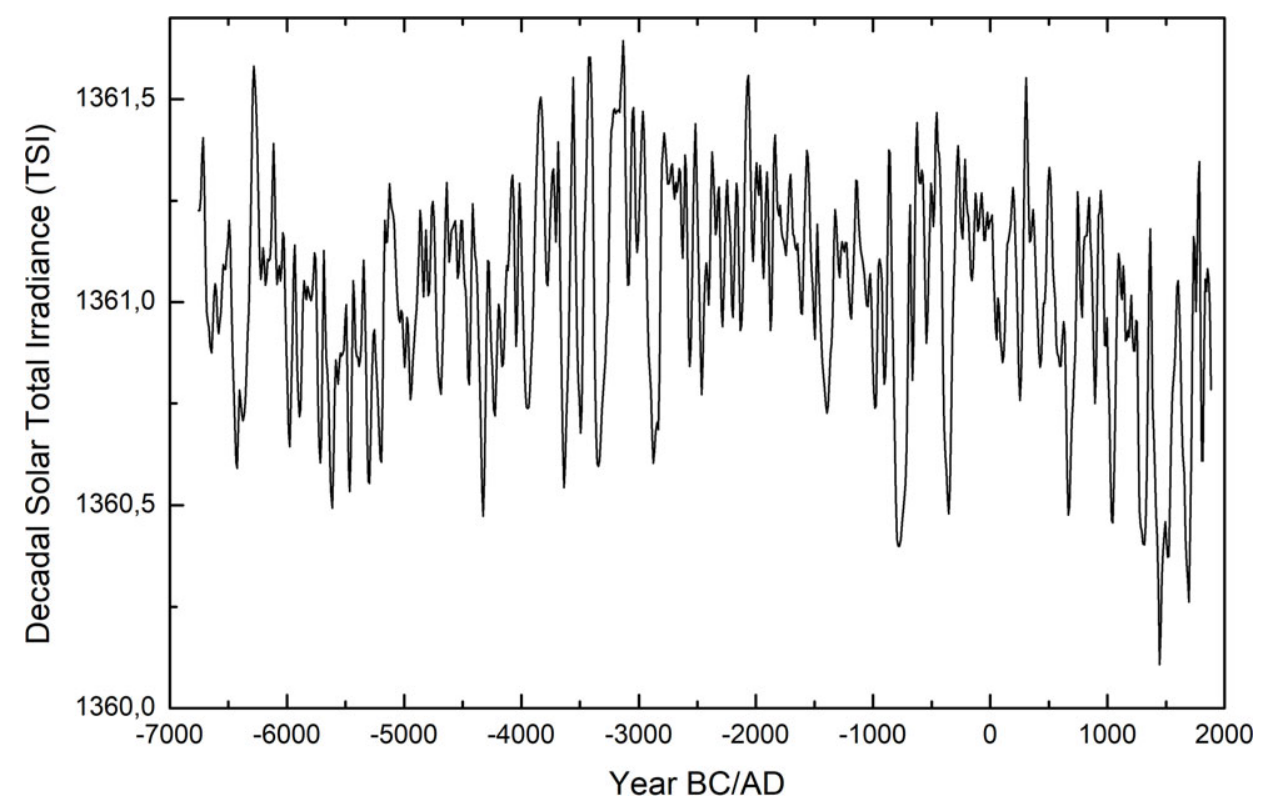

Figure 4 Total solar irradiance reconstructed from ${ }^{14} \mathrm{C}$ (IntCal09) and six ${ }^{10} \mathrm{Be}$ data sets from polar ice core archives. (Reproduced from Wu et al. 2018a.)

The high-resolution solar data, and the 774-775 CE event in particular, have been used as a chronological anchor point to secure the dating of ice-core records (Sigl et al. 2015) and to improve the dating of a number of "floating" tree-ring sequences (i.e., sequences that are not dendrochronologically anchored to the present with exact calendar dates using the tree-ring dating methods previously described). The replication of the 774/775 CE event in multiple global locations has also proved useful for exploring ideas about latitudinal, regional and laboratory offsets (Büntgen et al. 2018). Wacker et al. (2014) demonstrated how the 774-775 CE marker event could be used effectively (along with traditional dendrochronological techniques) to provide a precise and accurate construction date for wood samples from the St. John convent in Müstair, Switzerland, a UNESCO Word Heritage Site. Similarly, anchoring a tree-ring sequence on the 774-775 CE event allowed Oppenheimer et al. (2017) and Hakozaki et al. (2018) to date the volcanic eruption of Changbaishan, on the China-North Korea border, to late 946 CE. It also allowed Pearl et al. (2020) to establish and secure a paleoenvironmentally significant 2500-year-long Atlantic white cedar (Chamaecyparis thyoides) chronology from the Northeastern United States. The revolutionary potential of this approach in archaeological contexts has been well emphasized by Dee and Pope (2016) and has been demonstrated to dramatic effect when Kuitems et al. (2020) used the event to resolve the origins of the Uyghur monument of Por-Bajin in Russia, dating construction to the summer of $777 \mathrm{CE}$ and resolving decades of debate.

\section{The ${ }^{10} \mathrm{Be}$ Connection}

Changes in ${ }^{14} \mathrm{C}$ over time are directly related to atmospheric ${ }^{14} \mathrm{CO}_{2}$, which registers production changes caused by the solar/magnetic variability previously described. This variability simultaneously produces a record of ${ }^{10} \mathrm{Be}$ that is preserved as a parallel record in the polar ice cores. This can provide multiple advantages. Prior to the beginning of the continuous 
tree-ring-based ${ }^{14} \mathrm{C}$ calibration data (i.e., before 14,000 cal BP), the temporal resolution of the ${ }^{14} \mathrm{C}$ data from speleothems, lake and marine sediments, and corals is coarser, leading to some attenuation of the atmospheric ${ }^{14} \mathrm{C}$ variability, which is thus less accurate for calibration purposes. However, floating tree-ring series, found for various intervals in glacial times in both hemispheres, can be independently fixed in time by matching the ${ }^{14} \mathrm{C}$ from such samples with the ${ }^{10} \mathrm{Be}$ ice record that extends beyond the secure tree-ring record. Once in the correct temporal position, the tree-ring ${ }^{14} \mathrm{C}$ can then be used to improve the resolution of the calibration data for such time periods. For example, bidecadal ${ }^{14} \mathrm{C}$ measurements across 2000 rings of New Zealand kauri around Heinrich event 3 (Turney et al. 2016), placed in time relative to the ${ }^{10} \mathrm{Be}$ record from the GRIP ice cores, now refines the IntCal20 calibration data (compared to IntCal13) for the period ca. 30,000 cal BP. In that case, some ambiguity over the temporal ${ }^{14} \mathrm{C}$ position relative to the ${ }^{10} \mathrm{Be}$ record was resolved by the use of D-O (Dansgaard-Oeschger) phase 3, as recorded in the Cariaco climate proxy, to confirm the dating. Similarly, kauri was also measured in decadal blocks across 1300 years around the time of the Laschamps geomagnetic minimum event, showing the strong rise of $\Delta^{14} \mathrm{C}$ caused by the event. The link to a ${ }^{10} \mathrm{Be}$ reconstruction provided an ice core-based age of $42,500 \mathrm{cal} \mathrm{BP}$, which was 1000 years younger compared to the Hulu cave ${ }^{14} \mathrm{C}$ ages (Turney et al. 2010), possibly resulting from carbon cycle changes causing different signals in ${ }^{14} \mathrm{C}$. A detailed discussion is presented in Staff et al. (2019). Meanwhile, Scots pine and other sub-fossil trees from Northern Italy sampled at 5- and 10-year resolution show large age variations ca. $12,400{ }^{14} \mathrm{C}$ years $\mathrm{BP}$ during the Bølling warm phase, which were not evident in the coarser resolution IntCall3 data, but could clearly be seen in the GRIP ${ }^{10} \mathrm{Be}$ record. These tree-ring ${ }^{14} \mathrm{C}$ series were included in IntCal20, resulting in a wide calendar age bias for the onset of Greenland Interstadial 1 (Bølling chronozone), shown in Fig. 9 of Adolphi et al. (2017). Finally, for the Holocene period, where tree-ring ${ }^{14} \mathrm{C}$ is calendar secured, the comparison with ${ }^{10} \mathrm{Be}$ from the ice cores has instead been used to fine tune the chronological precision of the ice cores (e.g., Adolphi and Muscheler 2016) and to explore these combined records to improve our understanding of solar dynamics and to quantify the solar influence on climate (e.g., Steinhilber et al. 2012).

\section{WHAT'S NEXT?}

The future directions for tree-ring based radiocarbon research will likely include large-scale creation and replication of multi-millennial, multi-regional time series of annual (or sub-annual) measurements of ${ }^{14} \mathrm{C}$ from individual dated tree-rings (e.g., Kudsk et al. 2019; FogtmannSchulz 2019; Friedrich et al. 2020; Pearson et al. 2018, 2020b; Fahrni et al. 2020; Brehm et al. 2021). Such data are now well established in terms of feasibility/quality of measurement (Sookdeo et al. 2020; Wacker et al. 2010), dynamic multi-purpose functionality and scientific value. There now seems a strong basis (Friedrich et al. 2020; Pearson et al. 2018, 2020b) for such data to be used to refine the structure of future iterations of the radiocarbon calibration curves as these community-based resources continue to evolve and improve (Reimer et al. 2020; Hogg et al. 2020). The current Northern Hemisphere IntCal data now include annual data from trees from across Europe, North America, and Japan (for a comprehensive review and future recommendations see Bayliss et al. 2020), and it seems likely that both the geographic and temporal spread of such data (with inter-laboratory replication) will increase for both hemispheres. In the Southern Hemisphere there is particular potential for earlier time periods, in combination with ${ }^{10} \mathrm{Be}$, from New Zealand's swamp kauri (preserved in anoxic bog environments similar to the Irish oaks) that span a remarkable range of time periods extending back over 70,000 years (Turney et al. 2010; Lorrey et al. 2018). It also seems likely that an 
increasing number of annually resolved floating tree-ring series will be created to more finely delineate climatic events in Northern Hemisphere calibration data e.g., Capano et al. (2020).

While multi-regional, annually resolved ${ }^{14} \mathrm{C}$ time series undoubtedly have a future role in calibration, such data are multi-functional and the driving force for their creation may also (instead) come from applications to explore and predict the occurrence of solar/magnetic phenomena (Miyake et al. 2017; Park et al. 2017; O’Hare et al. 2019; Fahrni et al. 2020), gain new insights into the role of solar forcing in different climatic regions (Land et al. 2020), and be used to synchronize with other high-resolution paleoclimatic proxy evidence (e.g., Reinig et al. 2020). The continued two-way feedbacks between dendrochronology and radiocarbon will likely see both an increased use of single-year tree-ring based ${ }^{14} \mathrm{C}$ determinations to secure floating tree-ring sequences, either using SPEs (e.g., Kuitems et al. 2020) or using other subdecadal structure revealed by annual ${ }^{14} \mathrm{C}$ (e.g., Pearson et al. 2020a) or to provide independent verification of the dendrochronological dating of others (discussed by Büntgen et al. 2018). The same annual tree-ring based ${ }^{14} \mathrm{C}$ data will also be used to explore further questions of small-scale regional or latitudinal ${ }^{14} \mathrm{C}$ variability (see Reimer et al. (2020), Bayliss et al. (2020) for in-depth discussion, plus data in Büntgen et al. (2018), Pearson et al. (2020a, 2020b). There are also considerable new possibilities to trace the movement of the ITCZ through time using ${ }^{14} \mathrm{C}$ in tropical tree-rings as a means of climatic modeling, as well as in accessing parallel, highly resolved contemporaneous records of marine ${ }^{14} \mathrm{C}$, by crossdating tree-ring and marine sequences (Black et al. 2019).

This brief overview of the interwoven history of dendrochronology and radiocarbon advancements, exploration of cosmogenic isotopes, and study of solar magnetic activity, has demonstrated the complexity and productivity of the interactions between these fields. The high scientific relevance of the data generated has stimulated substantial progress in building millennia-long chronologies, greatly improving precision in isotope techniques, and advancing models of heliomagnetic impacts on the Earth's climate. The data have also revealed the previously unknown presence and intensity of extreme solar proton events, potentially harmful to technology on Earth. Future pathways will undoubtedly result in an impressive further array of interdisciplinary research.

\section{ACKNOWLEDGMENTS}

With thanks to P. Brewer, Curator of Collections at the Laboratory of Tree-Ring Research for support with locating and accessing archived materials and to M.G.L. Baillie for provision of images D and E, Figure 3. We also thank two anonymous reviewers and Paula Reimer for suggestions that much improved the manuscript. CP acknowledges support from the Malcolm H. Wiener Foundation. IU acknowledges support of the Academy of Finland (project No. 321882 ESPERA).

\section{REFERENCES}

Adolphi F, Muscheler R. 2016. Synchronizing the Greenland ice core and radiocarbon timescales over the Holocene-Bayesian wiggle-matching of cosmogenic radionuclide records. Climate of the Past 12(1):15-30.

Adolphi F, Muscheler R, Friedrich M, Güttler D, Wacker L, Talamo S, Kromer B. 2017.
Radiocarbon calibration uncertainties during the last deglaciation: Insights from new floating tree-ring chronologies. Quaternary Science Reviews 170:98-108.

Arnold JR, Libby WF. 1949. Age determinations by radiocarbon content: Checks with samples of known age. Science 109(2869):678-80. 
Baillie MGL. 2009. The radiocarbon calibration from an Irish oak perspective. Radiocarbon 51(1): 361-371.

Baillie MGL, Pilcher JR. 1987. The Belfast "Long Chronology" project. British Archaeological Reports (International Series 3.3). p. 203-14.

Bayliss A, Marshall P, Dee MW, Friedrich M, Heaton TJ, Wacker L. 2020. IntCal20 tree rings: an archaeological SWOT analysis. Radiocarbon 62(4):1045-1078.

Becker B. 1983. The long-term radiocarbon trend of the absolute German oak tree-ring chronology, 2800 to 800 BC. Radiocarbon 25(2):197-203.

Becker B. 1992. The history of dendrochronology and radiocarbon calibration. In: Taylor RE, Long A, Kra RS, editors. Radiocarbon after four decades. New York: Springer. doi: 10.1007/978-1-47574249-7_4.

Becker B. 1993. An 11,000-year German oak and pine dendrochronology for radiocarbon calibration. Radiocarbon 35(1):201-213.

Becker B, Schmidt B. 1982. Verlängerung der mitteleuropäischen Eichenjahrring-Chronologie in das zweite vorchristliche Jahrtausend (bis $1462 \mathrm{v}$. Chr.). Archäologisches Korrespondenzblatt 12:101-106.

Becker B, Schmidt B. 1990. Extension of the European oak chronology to the past 9924 years. In: Mook WG, Waterbolk HT, editors. Proceedings of the 2nd International Symposium, Archaeology and ${ }^{14} \mathrm{C}$ (Groningen, 1987). PACT 29:37-50.

Beer J, McCracken KG, von Steiger R. 2012. Cosmogenic radionuclides: theory and applications in the terrestrial and space environments. Berlin: Springer.

Beramendi-Orosco LE, Johnson KR, Noronha AL, González-Hernández $G$, Villanueva-Díaz J. 2018. High precision radiocarbon concentrations in tree rings from Northeastern Mexico: a new record with annual resolution for dating the recent past. Quaternary Geochronology 48:1-6.

Bernabei M. 2015. The age of the olive trees in the Garden of Gethsemane. Journal of Archaeological Science 53:43-48.

Black BA, Andersson C, Butler PG, Carroll ML, DeLong KL, Reynolds DJ, Schöne BR, Scourse J, van der Sleen P, Wanamaker AD, Witbaard R. 2019. The revolution of crossdating in marine palaeoecology and palaeoclimatology. Biology Letters 15(1):2018.0665.

Boswijk G, Fowler AM, Lorrey A, Palmer JG, Ogden J. 2006. Extension of the New Zealand kauri (Agathis australis) chronology to $1724 \mathrm{BC}$. The Holocene 16(2):188-199.

Boswijk G, Fowler AM, Palmer JG, Fenwick P, Hogg A, Lorrey A, Wunder J. 2014. The late Holocene kauri chronology: assessing the potential of a 4500-year record for palaeoclimate reconstruction. Quaternary Science Reviews 90: 128-142.

Braziunas TF, Fung IY, Stuiver M. 1995. The preindustrial atmospheric ${ }^{14} \mathrm{CO}_{2}$ latitudinal gradient as related to exchanges among atmospheric, oceanic, and terrestrial reservoirs. Global Biogeochemical Cycles 9(4):565-584.

Brehm N, Bayliss A, Christl M, Synal H-A, Adolphi F, Beer J, Kromer B, Muscheler R, Solanki SK, Usoskin I, et al. 2021. Eleven-year solar cycles over the last millennium revealed by radiocarbon in tree rings. Nature Geoscience 14(1):10-15.

Brown DM, Baillie MG. 2012. Confirming the existence of gaps and depletions in the Irish oak tree-ring record. Dendrochronologia 30(2):85-91.

Büntgen U, Wacker L, Galván JD, Arnold S, Arseneault D, Baillie M, Beer J, Bernabei M, Bleicher N, Boswijk G, et al. 2018. Tree rings reveal globally coherent signature of cosmogenic radiocarbon events in 774 and 993 CE. Nature Communications 9(1):3605.

Camarero JJ, Colangelo M, Gracia-Balaga A, Ortega-Martínez MA, Büntgen U. 2021. Demystifying the age of old olive trees. Dendrochronologia 65:125802.

Channell JET, Vigliotti L. 2019. The role of geomagnetic field intensity in Late Quaternary evolution of humans and large mammals. Reviews of Geophysics 57(3):709-738.

Cherubini P, Humbel T, Beeckman H, Gaertner H, Mannes D, Pearson C, Schoch W, Tognetti R, Lev-Yadun S. 2013. Olive tree-ring problematic dating: a comparative analysis on Santorini (Greece). PloS One 28;8(1):e54730.

Clark RM. 1978. Bristlecone pine and ancient Egypt: a re-appraisal. Archaeometry 20(1):5-17.

Cook ER, Buckley BM, Palmer JG, Fenwick P, Peterson MJ, Boswijk G, Fowler A. 2006. Millennia-long tree-ring records from Tasmania and New Zealand: a basis for modelling climate variability and forcing, past, present and future. 2006. Journal of Quaternary Science 21(7):689699.

Capano M, Miramont C, Shindo L, Guibal F, Marschal C, Kromer B, Tuna T, Bard E. 2020. Onset of the Younger Dryas recorded with ${ }^{14} \mathrm{C}$ at annual resolution in French subfossil trees. Radiocarbon 62(4):901-918.

Damon PE, Linick TW. 1986. Geomagneticheliomagnetic modulation of atmospheric radiocarbon production. Radiocarbon 28:266-278.

Damon PE, Peristykh AN. 2000. Radiocarbon calibration and application to geophysics, solar physics, and astrophysics. Radiocarbon 42(1):137-150.

Damon PE, Long A, Wallick EI. 1973. On the magnitude of the 11-year radiocarbon cycle. Earth and Planetary Science Letters 20(3): 300-306. 
Dean JS. 1997. Dendrochronology. In: Taylor RE, Aitken MJ, editors. Chronometric dating in archaeology. Advances in archaeological and museum science. Vol. 2. Boston: Springer. doi: 10.1007/978-1-4757-9694-0_2.

Dee MW, Pope BJ. 2016. Anchoring historical sequences using a new source of astrochronological tie-points. Proceedings of the Royal Society A: Mathematical, Physical and Engineering Sciences 472(2192):20160263.

Douglass AE. 1929. The secret of the Southwest solved by talkative tree rings. National Geographic, 56(6):737-770.

de Vries H. 1958. Variation in concentration of radiocarbon with time and location on earth. Proceedings of The Koninklijke Nederlandse Akademie Van Wetenschappen Series B 61: 94-102.

de Vries H. 1959. Measurement and use of natural radiocarbon. In: Abelson $\mathrm{PH}$, editor. Researches in geochemistry. New York: John Wiley \& Sons. p. 169-189.

Eastoe CJ, Tucek CS, Touchan R. 2019. $\Delta{ }^{14}$ C and $\delta^{13} \mathrm{C}$ in annual tree-ring samples from Sequoiadendron giganteum, AD 998-1510: Solar cycles and climate. Radiocarbon 61(3):661-680.

Ehrlich Y, Regev L, Boaretto E. 2018. Radiocarbon analysis of modern olive wood raises doubts concerning a crucial piece of evidence in dating the Santorini eruption. Scientific Reports 8(1): $1-8$.

Ehrlich Y, Regev L, Boaretto E. 2021. Discovery of annual growth in a modern olive branch based on carbon isotopes and implications for the Bronze Age volcanic eruption of Santorini. Scientific Reports 11(1):1-11.

Eronen M, Zetterberg P, Briffa KR, Lindholm M, Meriläinen J, Timonen M. 2002. The supralong Scots pine tree-ring record for Finnish Lapland: Part 1, chronology construction and initial inferences. 2002. The Holocene 12(6): 673-680.

Fahrni SM, Southon J, Fuller BT, Park J, Friedrich M, Muscheler R, Wacker L, Taylor RE. 2020. Single-year German oak and Californian bristlecone pine ${ }^{14} \mathrm{C}$ data at the beginning of the Hallstatt Plateau from $856 \mathrm{BC}$ to $626 \mathrm{BC}$. Radiocarbon 62(4):919-937.

Ferguson CW, Huber B, Suess HE. 1966. Determination of the age of Swiss lake dwellings as an example of dendrochronologicallycalibrated radiocarbon dating. Zeitschrift für Naturforschung Teil A:1173-1177.

Ferguson CW. 1969. A 7104-year annual tree-ring chronology for bristlecone pine, Pinus aristata, from the White Mountains, California. TreeRing Bulletin 29(3-4):3-29.

Fogtmann-Schulz A, Kudsk SGK, Trant PLK, Baittinger C, Karoff C, Olsen J, Knudsen MF. 2019. Variations in solar activity across the Spörer Minimum based on radiocarbon in
Danish oak. Geophysical Research Letters 46(15):8617-8623.

Fogtmann-Schulz A, Baittinger C, Karoff C, Olsen J, Knudsen MF. 2020. Changes in solar activity during the Wolf Minimum- new insights from a high resolution ${ }^{14} \mathrm{C}$ record based on Danish oak. Radiocarbon 63(1):91-104.

Friedrich M, Remmele S, Kromer B, Hofmann J, Spurk M, Kaiser KF, Orcel C, Küppers M. 2004. The 12,460-year Hohenheim oak and pine tree-ring chronology from central Europe-A unique annual record for radiocarbon calibration and paleoenvironment reconstructions. Radiocarbon 46(3):1111-1122.

Friedrich WL, Kromer B, Friedrich M, Heinemeier J, Pfeiffer T, Talamo S. 2006. Santorini eruption radiocarbon dated to $1627-1600$ B.C. Science 312:548.

Friedrich WL, Kromer B, Friedrich M, Heinemeier J, Pfeiffer T, Talamo S. 2014. The olive branch chronology stands irrespective of tree-ring counting. Antiquity 88(339):274-277.

Friedrich R, Kromer B, Sirocko F, Esper J, Lindauer S, Nievergelt D, Heussner KU, Westphal T. 2019. Annual ${ }^{14} \mathrm{C}$ tree-ring data around $400 \mathrm{AD}$ : midand high-latitude records. Radiocarbon 61(5):1305-1316.

Friedrich R, Kromer B, Wacker L, Olsen J, Remmele S, Lindauer S, Land A, Pearson C. 2020. A new annual ${ }^{14} \mathrm{C}$ dataset for calibrating the Thera eruption. Radiocarbon 62(4):953-961.

Gray LJ, Beer J, Geller M, Haigh JD, Lockwood M, Matthes K, Cubasch U, Fleitmann D, Harrison G, Hood L, et al. 2010. Solar influence on climate. Reviews of Geophysics 48(4):RG4001.

Güttler D, Adolphi F, Beer J, Bleicher N, Boswijk G, Christl M, Hogg A, Palmer J, Vockenhuber C, Wacker L, Wunder J. 2015. Rapid increase in cosmogenic ${ }^{14} \mathrm{C}$ in $\mathrm{AD} 775$ measured in New Zealand kauri trees indicates short-lived increase in ${ }^{14} \mathrm{C}$ production spanning both hemispheres. Earth and Planetary Science Letters 411:290-297.

Haigh JD. 2007. The Sun and the Earth's climate. Living Reviews in Solar Physics 4(1):2.

Hakozaki M, Miyake F, Nakamura T, Kimura K, Masuda K, Okuno M. 2018. Verification of the annual dating of the 10th century Baitoushan Volcano eruption based on an AD 774-775 Radiocarbon spike. Radiocarbon 60(1):261.

Hantemirov RM, Shiyatov SG. 2002. A continuous multimillennial ring-width chronology in Yamal, northwestern Siberia. The Holocene 12(6):717-726.

Hollstein E. $1980 . \quad$ Mitteleuropaische Eichenchronologie. Phillip von Zabern, Mainz am Rhein.

Hogg AG, Heaton TJ, Hua Q, Palmer JG, Turney CS, Southon J, Bayliss A, Blackwell PG, Boswijk G, Ramsey CB, Pearson C. 2020. 
SHCal20 Southern Hemisphere calibration, 055,000 years cal BP. Radiocarbon 62(4):759-778.

Hogg AG, Hua Q, Blackwell PG, Niu M, Buck CE, Guilderson TP, Heaton TJ, Palmer JG, Reimer PJ, Reimer RW, Turney CSM. 2013. SHCal 13 Southern Hemisphere calibration, 0-50,000 cal. years BP. Radiocarbon 55:1889-1903.

Hogg AG, McCormac FG, Higham TF, Reimer PJ, Baillie MG, Palmer JG. 2002. High-precision radiocarbon measurements of contemporaneous tree-ring dated wood from the British Isles and New Zealand: AD 1850-950. Radiocarbon 44(3):633-640.

Jacobel AW, McManus JF, Anderson RF, Winckler G. 2017. Climate-related response of dust flux to the central equatorial Pacific over the past 150 kyr. Earth and Planetary Science Letters 457: 160-172.

Jull AJT, Panyushkina IP, Miyake F, Masuda K, Nakamura T, Mitsutani T, Lange TE, Cruz RJ, Baisan C, Janovics R, et al. 2018. More rapid ${ }^{14} \mathrm{C}$ excursions in the tree-ring record: a record of different kind of solar activity at about 800 BC? Radiocarbon 60(4):1237-1248.

Jull AJT, Panyushkina IP, Molnár M, Varga T, Wacker L, Brehm N, Laszló E, Baisan C, Salzer MW, Tegel W. 2021. Rapid ${ }^{14} \mathrm{C}$ excursion at 3372-3371 BCE not observed at two different locations. Nature Communications 12(1):712.

Kono M, editor. 2007. Treatise on geophysics. Vol. 5: geomagnetism. Elsevier.

Kromer B. 2009. Radiocarbon and dendrochronology. Dendrochronologia 27(1):15-19.

Kudsk SGK, Philippsen B, Baittinger C, FogtmannSchulz A, Knudsen MF, Karoff C, Olsen J. 2019. New single-year radiocarbon measurements based on Danish oak covering the periods AD 692-790 and 966-1057. Radiocarbon 62(4): 969-987.

Kuitems M, Panin A, Scifo A, Arzhantseva I, Kononov Y, Doeve P, Neocleous A, Dee M. 2020. Radiocarbon-based approach capable of subannual precision resolves the origins of the site of Por-Bajin. Proceedings of the National Academy of Sciences 117(25):14038-14041.

Land A, Kromer B, Remmele S, Brehm N, Wacker L. 2020. Complex imprint of solar variability on tree rings. Environmental Research Communications 2(10): 101003 .

Leavitt SW, Bannister B. 2009. Dendrochronology and radiocarbon dating: The Laboratory of Tree-Ring Research connection. Radiocarbon 51:373-384.

Leavitt SW, Panyushkina IP, Grissino-Mayer HD. 2012. Dendrochronology. In: Encyclopedia of Science \& Technology, 11th Edition. McGraw Hill.

Leuschner HH, Delorme, A. 1984. Verlängerung der Göttinger Eichenjahrringchronologien für Nordund Süddeutschland bis zum Jahr 4008 v. Chr., Forstarchiv 55(1):1-4.
Libby WF. 1961. Radiocarbon dating. Science 133(3453):621-629.

Lingenfelter RE. 1963. Production of carbon 14 by cosmic - ray neutrons. Reviews of Geophysics. 1(2):35-55.

Lorrey AM, Boswijk G, Hogg A, Palmer JG, Turney, CS Fowler, AM Ogden J, Woolley JM. 2018. The scientific value and potential of New Zealand swamp kauri. Quaternary Science Reviews 183:124-139.

Marsh EJ, Bruno MC, Fritz SC, Baker P, Capriles JM, Hastorf CA. 2018. IntCal, SHCal, or a mixed curve? Choosing a ${ }^{14} \mathrm{C}$ calibration curve for archaeological and paleoenvironmental records from tropical South America. Radiocarbon 60(3):925.

McCormac FG, Baillie MGL, Pilcher JR, Kalin RM. 1995. Location-dependent differences in the ${ }^{14} \mathrm{C}$ content of wood. Radiocarbon 37(2):395-407.

McCormac FG, Hogg AG, Blackwell PG, Buck CE, Higham TF, Reimer PJ. 2004. SHCal04 Southern Hemisphere calibration, 0-11.0 cal kyr BP. Radiocarbon 46(3):1087-1092.

McCormac FG, Reimer PJ, Hogg AG, Higham TFG, Baillie MGL, Palmer J, Stuiver M. 2002. Calibration of the radiocarbon time scale for the Southern Hemisphere: AD 1850-950. Radiocarbon 44(3):641-651.

McCormac FG, Hogg AG, Higham TFG, LynchStieglitz J, Broecker WS, Baillie MGL, Palmer J, Xiong L, Pilcher JR, Brown D, Hoper ST. 1998. Temporal variation in the interhemispheric ${ }^{14} \mathrm{C}$ offset. Geophysical Research Letters 25:1321-1324.

Mekhaldi F, Muscheler R, Adolphi F, Aldahan A, Beer J, McConnell JR, Possnert G, Sigl M, Svensson A, Synal H-A, et al. 2015. Multiradionuclide evidence for the solar origin of the cosmic-ray events of AD 774/5 and 993/ 4. Nature Communications 6(1):8611.

Miyake F, Masuda K, Nakamura T. 2013. Another rapid event in the carbon-14 content of tree rings. Nature Communications 4:1748.

Miyake F, Masuda K, Nakamura T, Kimura K, Hakozaki M, Jull AT, Lange TE, Cruz R, Panyushkina IP, Baisan C, Salzer MW. 2017. Search for annual ${ }^{14} \mathrm{C}$ excursions in the past. Radiocarbon: 59(2):315-320.

Miyake F, Nagaya K, Masuda K, Nakamura T. 2012. A signature of cosmic-ray increase in AD 774-775 from tree rings in Japan. Nature 486(7402):240-242.

Moriya T, Miyahara H, Ohyama M, Hakozaki M, Takeyama M, Sakurai H, Tokanai F. 2019. A study of variation of the 11-yr solar cycle before the onset of the Spoerer Minimum based on annually measured ${ }^{14} \mathrm{C}$ content in tree rings. Radiocarbon 61(6):1749-1754.

Muscheler R, Adolphi F, Heaton TJ, Bronk Ramsey C, Svensson A, van der Plicht J, Reimer PJ. 2020. Testing and improving the IntCal20 calibration 
curve with independent records. Radiocarbon 62(4):1079-1094.

Neuhäuser R, Neuhäuser, DL. 2015. Variations of ${ }^{14} \mathrm{C}$ around AD 775 and AD $1795-$ due to solar activity. Astronomische Nachrichten 336(10):930-954.

Nicolussi K, Kaufmann M, Melvin TM, van der Plicht J, Schießling P, Thurner A. 2009. A 9111 year long conifer tree-ring chronology for the European Alps: a base for environmental and climatic investigations. The Holocene 19(6):909-920.

Nilsson A, Holme R, Korte M, Suttie N, Hill M. 2014. Reconstructing Holocene geomagnetic field variation: new methods, models and implications. Geophysical Journal International 198(1):229-248.

O'Hare P, Mekhaldi F, Adolphi F, Raisbeck G, Aldahan A, Anderberg E, Beer J, Christl M, Fahrni S, Synal H-A, et al. 2019. Multiradionuclide evidence for an extreme solar proton event around 2,610 B.P. ( 660 BC). Proceedings of the National Academy of Sciences 116(13):5961-5966.

Oppenheimer C, Wacker L, Xu J, Galván JD, Stoffel M, Guillet S, Corona C, Sigl M, Di Cosmo N, Hajdas I, Pan B. 2017. Multi-proxy dating the "Millennium Eruption" of Changbaishan to late 946 CE. Quaternary Science Reviews 158: 164-171.

Park J, Southon J, Fahrni S, Creasman PP, Mewaldt R. 2017. Relationship between solar activity and $\Delta^{14} \mathrm{C}$ peaks in AD 775, AD 994, and $660 \mathrm{BC}$. Radiocarbon 59(4):1147-1156.

Patrut A, Karl F, Van Pelt R, Mayne DH, Lowy DA, Margineanu D. 2011. Age determination of large live trees with inner cavities: radiocarbon dating of Platland tree, a giant African baobab. Annals of Forest Science 68(5):993-1003.

Pearl JK, Anchukaitis KJ, Donnelly JP, Pearson C, Pederson N, Gaylord MC, McNichol AP, Cook ER, Zimmermann GL. 2020. A late Holocene subfossil Atlantic white cedar tree-ring chronology from the northeastern United States. Quaternary Science Reviews 228: 106104.

Pearson CL, Brewer PW, Brown D, Heaton TJ, Hodgins GW, Jull AT, Lange T, Salzer MW. 2018. Annual radiocarbon record indicates 16th century BCE date for the Thera eruption. Science Advances 4(8):eaar8241.

Pearson CL, Salzer M, Wacker L, Brewer P, Sookdeo A, Kuniholm P. 2020a. Securing timelines in the ancient Mediterranean using multiproxy annual tree-ring data. Proceedings of the National Academy of Sciences 117(15):8410-8415.

Pearson CL, Wacker L, Bayliss A, Brown D, Salzer M, Brewer P, Bollhalder S, Boswijk G, Hodgins G. 2020b. Annual variation in atmospheric ${ }^{14} \mathrm{C}$ between $1700 \mathrm{BC}$ and $1480 \mathrm{BC}$. Radiocarbon 62(4):939-952.
Pearson GW, Pilcher JR, Baillie MG, Corbett DM, Qua F. 1986. High-precision ${ }^{14} \mathrm{C}$ measurement of Irish oaks to show the natural ${ }^{14} \mathrm{C}$ variations from AD 1840 to 5210 BC. Radiocarbon 28(2B):911-934.

Pilcher JR. Biological considerations in the interpretation of stable isotope ratios in oak treerings. 1995. Paläoklimaforschung 15:157-161.

Pilcher JR, Baillie MGL, Schmidt B, Becker B. 1984. A 7,272-year tree-ring chronology for Western Europe. Nature 312:150-152.

Pritchett DW. 2021. Finding Methuselah: new light on an old story. Tree-Ring Research 77(1):20-31.

Reimer PJ. 2004. IntCal04: terrestrial radiocarbon age calibration, 0-26 cal kyr BP. Radiocarbon 46(3):1029-1058.

Reimer PJ, Austin WE, Bard E, Bayliss A, Blackwell PG, Ramsey CB, Butzin M, Cheng H, Edwards RL, Friedrich M, Grootes PM. 2020. The IntCal20 Northern Hemisphere radiocarbon age calibration curve (0-55 cal kBP). Radiocarbon 62(4):725-757.

Reimer PJ, Baillie MG, Bard E, Bayliss A, Beck JW, Blackwell PG, Ramsey CB, Buck CE, Burr GS, Edwards RL, Friedrich M. 2009. IntCal09 and Marine09 radiocarbon age calibration curves, 0-50,000 years cal BP. Radiocarbon 51(4): 1111-1150.

Reimer PJ, Bard E, Bayliss A, Beck JW, Blackwell PG, Ramsey CB, Buck CE, Cheng H, Edwards RL, Friedrich M, Grootes PM. 2013. IntCal13 and Marine13 radiocarbon age calibration curves $0-50,000$ years cal BP. Radiocarbon 55(4):1869-1887.

Reinig F, Sookdeo A, Esper J, Friedrich M, Guidobaldi G, Helle G, Kromer B, Nievergelt D, Pauly M, Tegel W, Treydte K. 2020. Illuminating IntCal during the Younger Dryas. Radiocarbon 62(4):883-889.

Salzer, MW, Pearson, CL, Baisan, CH. 2019. Dating the Methuselah Walk bristlecone pine floating chronologies. Tree-Ring Research 75(1):61-66.

Santos GM, Granato-Souza D, Barbosa AC, Oelkers R, Andreu-Hayles L. 2020. Radiocarbon analysis confirms annual periodicity in Cedrela odorata tree rings from the equatorial Amazon. Quaternary Geochronology 58:101079.

Schulman E. 1954. Longevity under adversity in conifers. Science 119(3091):396-399.

Scifo A, Kuitems M, Neocleous A, Pope BJS, Miles D, Jansma E, Doeve P, Smith AM, Miyake F, Dee MW. 2019. Radiocarbon production events and their potential relationship with the Schwabe cycle. Scientific Reports 9(1):1-8.

Sigl M, Winstrup M, McConnell JR, Welten KC, Plunkett G, Ludlow F, Büntgen U, Caffee M, Chellman N, Dahl-Jensen D, Fischer H. 2015. Timing and climate forcing of volcanic eruptions for the past 2,500 years. Nature 523(7562):543-549. 
Solanki SK, Krivova NA, Haigh JD. 2013. Solar irradiance variability and climate. Annual Review of Astronomy and Astrophysics 51(1):311-351.

Solanki SK, Usoskin IG, Kromer B, Schüssler M, Beer J. 2004. Unusual activity of the Sun during recent decades compared to the previous 11,000 years. Nature 431:1084-1087.

Sonett CP, Finney SA. 1990. The spectrum of radiocarbon. Philosophical Transactions of the Royal Society of London. Series A, Mathematical and Physical Sciences 330: 413-426. doi: 10.1098/rsta.1990.0022.

Sookdeo A, Kromer B, Büntgen U, Friedrich M, Friedrich R, Helle G, Pauly M, Nievergelt D, Reinig F, Treydte K, Synal HA. 2020. Quality dating: a well-defined protocol implemented at ETH for high-precision ${ }^{14} \mathrm{C}$-dates tested on late glacial wood. Radiocarbon 62(4):891-899.

Speer J. 2010. Fundamentals of tree-ring research. Tucson (AZ): University of Arizona Press. 368 p. ISBN: 978-0-816-52684-0.

Staff RA, Hardiman M, Bronk Ramsey C, Adolphi F, Hare VJ, Koutsodendris A, Pross J. 2019. Reconciling the Greenland ice-core and radiocarbon timescales through the Laschamps geomagnetic excursion. Earth and Planetary Science Letters 520:1-9.

Steinhilber F, Abreu JA, Beer J, Brunner I, Christl M, Fischer H, Heikkilä U, Kubik PW, Mann M, McCracken KG, et al. 2012. 9,400 years of cosmic radiation and solar activity from ice cores and tree rings. Proceedings of the National Academy of Sciences 109(16):5967-5971.

Stuiver M. 1961. Variations in radiocarbon concentration and sunspot activity. Journal of Geophysical Research 66(1):273-276.

Stuiver M. 1965. Carbon-14 content of 18th- and 19th-century wood: variations correlated with sunspot activity. Science 149(3683):533-534.

Stuiver M. 1993. A note on single-year calibration of the radiocarbon time scale, AD 1510-1954. Radioccarbon 35(1):67-72.

Stuiver M, Braziunas TF. 1993. Sun, ocean, climate and atmospheric ${ }^{14} \mathrm{CO}_{2}$ : an evaluation of causal and spectral relationships. The Holocene 3(4):289-305.

Stuiver M, Braziunas TF, Becker B, Kromer B. 1991. Climatic, solar, oceanic, and geomagnetic influences on late-glacial and Holocene atmospheric ${ }^{14} \mathrm{C} /{ }^{12} \mathrm{C}$ change. Quaternary Research 35:1-24.

Stuiver M, Kromer B, Becker B, Ferguson CW. 1986. Radiocarbon age calibration back to 13,300 years $\mathrm{BP}$ and the ${ }^{14} \mathrm{C}$ age matching of the German oak and US bristlecone pine chronologies. Radiocarbon 28(2B):969-979.

Stuiver M, Quay P. 1980. Changes in atmospheric ${ }^{14} \mathrm{C}$ attributed to a variable sun. Science 207:11-19.

Stuiver M, Reimer PJ, Bard E, Beck JW, Burr GS, Hughen KA, Kromer B, McCormac G, van der
Plicht J, Spurk M. 1998. IntCa198 radiocarbon age calibration, 24,000-0 cal BP. Radiocarbon 40(3):1041-1083.

Suess HE. 1955. Radiocarbon concentration in modern wood. Science 122(3166):415-417.

Suess HE. 1965. Secular variations of the cosmic-rayproduced carbon 14 in the atmosphere and their interpretations. Journal of Geophysical Research 70(23):5937-5952.

Suess HE. 1967. Bristlecone pine calibration of the radiocarbon time scale from $4100 \mathrm{BC}$ to 1500 BC. In: Radioactive dating and methods of low-level counting. Vienna: International Atomic Energy Agency. p. 143-151.

Suess HE. 1970. Bristlecone pine calibration of the radiocarbon time-scale, $5200 \mathrm{BC}$ to the present. In: Radiocarbon variations and absolute chronology: Proceedings of the Twelfth Nobel Symposium held at the Institute of Physics of Uppsala University. New York: John Wiley \& Sons. p. 303-311.

Sukhodolov T, Usoskin I, Rozanov E, Asvestari E, Ball WT, Curran MA, Fischer H, Kovaltsov G, Miyake F, Peter T, Plummer C. 2017. Atmospheric impacts of the strongest known solar particle storm of 775 AD. Scientific Reports 7(1):1-9.

Taylor EL, Ryberg PE. 2007. Tree growth at polar latitudes based on fossil growth ring analysis. Palaeogeography, Palaeoclimatology, Palaeoecology 255:246-264.

Turney CSM, Fifield LK, Hogg AG, Palmer JG, Hughen K, Baillie MGL, Galbraith R, Ogden J, Lorrey A, Tims SG, et al. 2010. The potential of New Zealand kauri (Agathis australis) for testing the synchronicity of abrupt climate change during the Last Glacial Interval (60,000-11,700 years ago). Quaternary Science Reviews 29(27-28):3677-3682.

Turney CSM, Palmer J, Bronk Ramsey C, Adolphi F, Muscheler R, Hughen KA, Staff RA, Jones RT, Thomas ZA, Fogwill CJ, et al. 2016. Highprecision dating and correlation of ice, marine and terrestrial sequences spanning Heinrich Event 3: Testing mechanisms of interhemispheric change using New Zealand ancient kauri (Agathis australis). Quaternary Science Reviews 137:126-134.

Usoskin IG, Kromer B, Ludlow F, Beer J, Friedrich M, Kovaltsov GA, Solanki SK, Wacker L. 2013. The AD 775 cosmic event revisited: The Sun is to blame. Astronomy \& Astrophysics 552(L3):1-4.

Usoskin IG, Solanki SK, Kovaltsov GA. 2007. Grand minima and maxima of solar activity: new observational constraints. Astronomy \& Astrophysics 471(1):301-309.

Uusitalo J, Arppe L, Hackman T, Helama S, Kovaltsov G, Mielikäinen K, Mäkinen H, Nöjd P, Palonen V, Usoskin I, Oinonen M. 2018. Solar superstorm of AD 774 recorded 
subannually by Arctic tree rings. Nature Communications 9(1):1-8.

Vieira S, Trumbore S, Camargo PB, Selhorst D, Chambers JQ, Higuchi N, Martinelli LA. 2005. Slow growth rates of Amazonian trees: Consequences for carbon cycling. Proceedings of the National Academy of Sciences 102(51):18502-18507.

Wacker L, Bonani G, Friedrich M, Hajdas I, Kromer B, Němec M, Ruff M, Suter M, Synal HA, Vockenhuber C. 2010. MICADAS: routine and high-precision radiocarbon dating. Radiocarbon 52(2):252-262.

Wacker L, Güttler D, Hurni JP, Synal H-A, Walti N. 2014. Radiocarbon dating to a single-year by means of rapid atmospheric ${ }^{14} \mathrm{C}$ changes. Radiocarbon 56(2):573-579

Wacker L, Scott EM, Bayliss A, Brown D, Bard E, Bollhalder S, Friedrich M, Capano M, Cherkinsky A, Chivall D, et al. 2020. Findings from an in-depth annual tree-ring radiocarbon intercomparison. Radiocarbon 62(4):873-882.
Wang FY, Yu H, Zou YC, Dai ZG, Cheng KS. 2017. A rapid cosmic-ray increase in BC 3372-3371 from ancient buried tree rings in China. Nature Communications 8(1):1487.

Webb GE. 1983. Tree rings and telescopes. The scientific career of AE Douglas. Tucson (AZ): University of Arizona Press.

Wu CJ, Krivova NA, Solanki SK, Usoskin IG. 2018a. Solar total and spectral irradiance reconstruction over the last 9000 years. Astronomy \& Astrophysics 620:A120.

Wu CJ, Usoskin IG, Krivova N, Kovaltsov GA, Baroni M, Bard E, Solanki SK. 2018b. Solar activity over nine millennia: a consistent multiproxy reconstruction. Astronomy \& Astrophysics 615:A93.

Zhao S, Pederson N, d'Orangeville L, HilleRisLambers J, Boose E, Penone C, Bauer B, Jiang Y, Manzanedo RD. 2019. The International Tree-Ring Data Bank (ITRDB) revisited: data availability and global ecological representativity. Journal of Biogeography 46(2):355-368. 